\title{
Research on the Status Quo and Development of Human Resources Incentive Mechanism in Higher Vocational Colleges
}

\author{
Yang Li \\ Personnel Division, Wuxi Vocational Institute of Commerce, Wuxi, 214153, China \\ email: gongwenzi1968@sina.com
}

\begin{abstract}
Keywords: higher vocational colleges, human resource management, incentive mechanism, current situation analysis, development strategy
\end{abstract}

\begin{abstract}
After a new round of extension and resource integration, higher vocational colleges are faced with many new situations and new problems. How to use incentive mechanism to promote the reform of human resources management system, to fully tap the potential of educating human resources - teachers and to realize higher vocational colleges health, rapid and sustainable development has become an important issue in the development process. Based on human resource management theory and motivation theory, this paper expounds the role of motivation mechanism in human resource management in higher vocational colleges and analyzes the problems existing in incentive mechanism of human resource management in higher vocational colleges. Based on the analysis of motivation factors of higher vocational colleges, this paper puts forward the development strategy of human resource management incentive mechanism, which provides theoretical guidance for the improvement of human resource management in higher vocational colleges.
\end{abstract}

\section{Introduction}

Higher vocational colleges, as knowledge and technology integration systems, are organizations that create, transmit and use knowledge. Higher vocational teachers are the main human resources organized by higher vocational colleges and the carriers of intellectual capital (knowledge, skills and wisdom) [1]. Compared with the human resources of other organizations, the higher vocational teachers have their distinctive characteristics. The effective use of the concept of intellectual capital management to innovate the performance management of higher vocational teachers can fully mobilize the enthusiasm and creativity of teachers, speed up the accumulation of human capital and promote the development of higher vocational education[2].

The key competitiveness of the organization survival and development in the era of knowledge economy is the talent. Establishing a highly qualified and dynamic faculty is the key to the healthy development of higher vocational colleges[3]. In the past, the existing personnel management mode in higher vocational colleges had different degrees of problems, and in some aspects it was obviously unable to meet the needs of teachers in higher vocational colleges in the era of knowledge-based economy[4]. The attractiveness of higher vocational colleges to talents gradually weakened, and the inside talents also experienced the phenomenon of job-hopping. There are many reasons for the brain drain in higher vocational colleges. In this paper, we think that the incentive mechanism is one of the most urgent problems to be solved. To solve the problem of core brain drain, we must set up a system that meets the characteristics of human resource management incentive mechanism[5]. By constructing a reasonable mode of incentive mechanism for higher vocational colleges, it is possible to realize the appointment system for the school in a real sense and retain the core talents for the school. In addition, a combination of reasonable and effective performance evaluation and performance management system can urge higher vocational colleges of faculty and staff create better job performance in a good work environment.

\section{The Concept of Human Resource Management and Incentive Mechanism}

Human Resource Management in Higher Vocational Colleges. Human resource management in 
higher vocational colleges refers to use scientific theories, principles and methods, according to the law of talent growth and the mission of the school, to plan and organize all levels of personnel in schools, to guide, coordinate and control the interpersonal and personnel relations so as to achieve the goal of high efficiency and high efficiency of utilization of human resources in colleges and universities by doing a good job in hiring and hiring faculty members, allocating and exchanging exchanges, awarding and dismissing appointments, training and assessment, salary and welfare, rank promotion, retirement and retirement. Specifically, human resource management in higher vocational colleges refers to the management of practitioners in higher vocational colleges from hiring, training, promotion, transfer and evaluation until the entire retirement. Its purpose is to achieve the goal of adapting itself to others, making the best use of its talents and competing for its accomplishments through scientific management and seeking the mutual coordination among faculty and staff, teachers and students, faculty and staff, education and social environment. The implementation of human resource management in higher vocational colleges is determined by the special nature and strategic status of higher vocational colleges. Higher vocational colleges are the places where talents gather and cultivate talents. Today, both the internal and external environment of higher vocational colleges have changed. The traditional personnel management has severely hampered the survival and development of higher vocational colleges. Therefore, increasing the development and management of human resources in higher vocational colleges is the inevitable choice for higher vocational colleges to win the fierce competition.

Incentive Mechanism. Incentive mechanism refers to the sum of the structure, mode, relationship and evolvement rules of the incentive system in the system of organization, which is driven by the system of motivation, standardized and relatively standardized, and interacted with the motivating object. It refers to the role of regulating the organization and motivating people by formulating and implementing certain policies, systems, laws and regulations and taking certain measures within the organization to create the functions of stimulating and motivating organizations and individuals, standardizing behaviors and guiding directions. A good incentive mechanism should have the following characteristics: 1 ) focus on material incentives to the spiritual incentive transition; 2) focus on the principle of combining goals; 3 ) focus on the principle of incentive; 4) focus on the principle of timeliness.

\section{The Role of Incentive Mechanism in Human Resource Management}

Necessity of Incentive Mechanism in Modern Organization and Management. The purpose of human resource management is to stimulate people's potential, to maximize the subjective initiative and creativity, to promote the realization of organizational goals and personal goals, and to promote social progress. Effective incentives can be a motivation for the development of your organization, inspiring your employees' potential energy and better working toward the organization's stated goals. In fact, it is to explore how to effectively motivate employees' morale and encourage their motivation. Unlike other management activities, incentives may not directly contribute to the interests of the organization, but it is the most reliable guarantee for the organization to achieve its goals. Therefore, introducing and making full use of incentive mechanism is a necessary requirement for the survival and further development of higher vocational colleges.

Incentive Needs of Human Resources in Higher Vocational Colleges. In the era of knowledge-based economy, human capital is the driving force to promote the national economy onto a sustainable development. Human resources are the primary resources. Doing well the development and management of human resources is the key to deepening the reform of personnel system in higher vocational colleges, optimizing the structure of teachers and improving the quality of education. Establishing a reasonable and effective incentive mechanism has a long-term significance for the development of our higher vocational colleges. As a type of higher education in our country, higher vocational education is different from ordinary undergraduate education. Therefore, the incentive of human resources in higher vocational colleges has its own particularity and complexity. The management of higher vocational colleges should be based on the actual situation in schools, with vocational education as the starting point, human resources management 
as the focus, scientific management as the means and incentive theory as the basis, to build a modern human resources management incentive mechanism with a new perspective and through continuous innovation.

\section{Problems in Incentive Mechanism of Human Resource Management}

In recent years, the management system of human resources development in higher vocational colleges in our country has undergone reforms and great achievements have also been made. While reform has achieved both achievements and problems, some accomplishments should be made clear. At the same time, we should clearly see the complexity, long-term and arduousness of the reform and make a careful plan. At present, the problems in human resource management incentive mechanism in higher vocational colleges mainly include:

(1) Incentives form a single cure, lack of change and scalability. At present, many vocational colleges have not undergone any investigation and research, and have not taken into consideration the individual factors such as individual age, psychological process, individual psychological tendency, personality traits, the complexity of teachers' work and different work environments, and the incentive measures curing a single, lack of change in the form of incentives and scalability.

(2) Incentive program design heavy material factors, ignoring the spirit of attention. Incentives for the program focused on monetary or material incentives, with little attention to spiritual incentives, ignoring the self-satisfaction of teachers and other factors to achieve satisfaction.

(3) Incentives rigid highlight, lack of flexibility. Rigid incentives are mandatory documents or regulations set by the government or regulatory agencies. At present, many rigid incentives of higher vocational colleges highlight the lack of flexible humanistic care and spiritual reward. Incentive documents only have certain qualifications, the provisions of the level of academic journals or the required awards to enjoy the appropriate treatment or promotion, so that teaching and research work to a certain extent become utilitarian.

(4) Lack of professional and technical job evaluation reliability, weakening the incentive mechanism. In the appraisal of professional titles, all kinds of awards and the training programs of personnel training at all levels of government, the teachers in higher vocational schools are not credible.

\section{Motivational Analysis of Teachers in Higher Vocational Colleges}

If performance leads to higher teacher satisfaction, this high level of satisfaction will enable teachers to maintain a high level of work effort. Therefore, the higher vocational colleges should shift the emphasis of incentive to the performance factor in the incentive system to form a virtuous circle, and bring such high satisfaction to the next round of systematic feedback to form a good systematic feedback. Figure 1 shows the impact of efforts include: expectations and valence, the choice of the degree of rational, preferences, stress and habitual strength. The direct link with the job performance of the factors are: environmental constraints, hard work, ability and so on. In addition, the fairness factor plays a significant role in the performance of the incentive system. Therefore, to excavate teachers 'motivation factors should not only focus on effort factors, but also focus on the main factors that produce performance. The following research on teachers' motivation factors focuses on controllable factors.

\section{Development Strategies of Incentive Measures in Human Resource Management in Higher Vocational Colleges}

Build an Effective Incentive Mechanism. How to effectively mobilize the enthusiasm and creativity of higher vocational college teachers, the key lies in how to establish an effective incentive mechanism. Now from the following two aspects to be analyzed. 


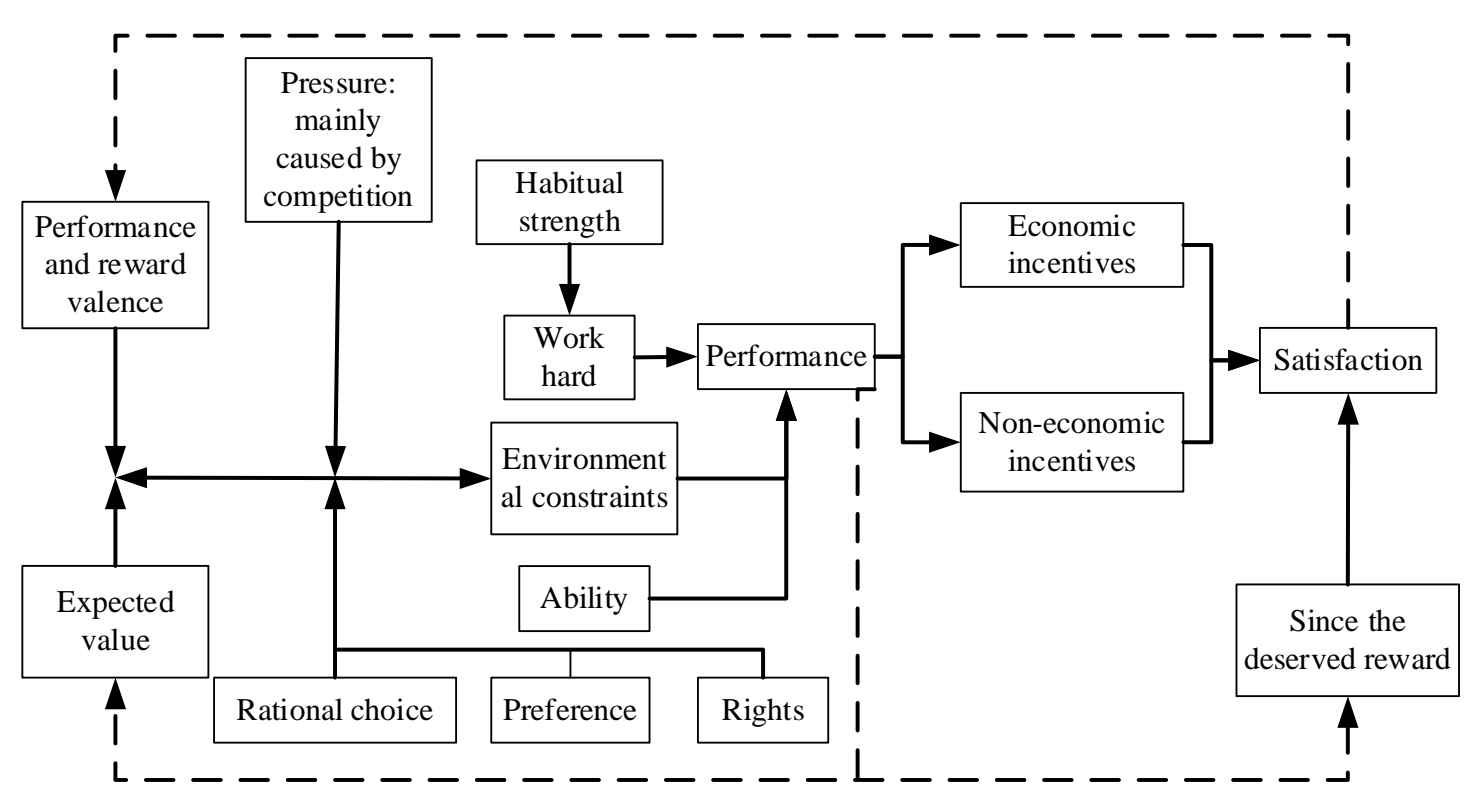

Figure 1 Extended incentive model

Incentive Mechanism should Pay Attention to the Form of Flexible and Diverse Subject Incentive with Individual Differences. The fundamental starting point of modern human resource management is "people-oriented". With "people" as the core, it emphasizes the regulation and development of a dynamic psychology and consciousness. Its management is attributed to the systematization of people and things. Under the socialist market economic system, the people's livelihood economy is the core of China's market economy, that is, it requires the state to pay more attention to whether the common interest needs of the common people have been met. As far as the special group of teachers is concerned. Under the great environment of market economy, they most hope that the personal value and ability literacy can be fully manifested and exerted.

Incentive Program Design should Pay Attention to the Combination of Material Incentives and Spiritual Incentives. Psychological studies show that everyone likes to be motivated, but also a variety of incentives, and social behavior is a "need - desire - satisfaction" cycle of chain reaction process. Incentives for teachers in higher vocational colleges are essentially the process of teachers' self-realization. According to the analysis of man's entire survival and development stage, human needs mainly manifest themselves in the needs of survival, social needs and development needs. Teachers in higher vocational colleges make their pursuit of their own value and realization of self-development due to their remarkable characteristics.

Build a Scientific and Rational Operation Mechanism. A scientific and rational operating mechanism should be built in order to achieve the goal of human resources development and management objectives and security. Scientific and reasonable operation mechanism, for vocational colleges, mainly includes four aspects: talent recruitment, training, evaluation and incentive mechanism.

It is Necessary to Set up the Personnel Recruitment Mechanism. We should improve the employment, optimize the allocation of human resources, avoid duplication of work and waste of personnel. The traditional human resource management system is a plan to employ the deployment, organization, administrative appointment. To fundamentally eradicate old habits, we must adhere to scientific and positioned, namely allocation create positions according to the teaching and administrative tasks.

Strengthen the Construction of "Double-qualified" Teaching Staff. "Double-teacher" refers to the teachers must have the professional ability to practice, that is, to teach the profession related to social job experience, qualifications or ability. Therefore, to strengthen the theory of the old teacher with practical experience at the same time, we should also strengthen the training of practical skills of young teachers without any practical experience in the enterprise.

The ISO9001 Quality Management System and a Scientific and Reasonable Personnel 
Evaluation Mechanism should be Established, and the Graduation of Teachers' title Evaluation and Reform should be Promoted Steadily. The evaluation and appointment of teachers in higher vocational colleges must break the system of tenure and unitary system. According to the teachers' true teaching ability and working ability, they should establish a multiple system of appointment and evaluation. Excellent teachers with special achievements or achievements can be given the opportunity This will be a great encouragement to many able-bodied young teachers and will further arouse their enthusiasm and enthusiasm in their work.

Create a Sound Employment Environment and Establish a Fair and Effective Competitive Incentive Mechanism. Talent incentive has always been an important issue of human resource management and development. It is an important condition for faculty and staff to maintain their enthusiasm for work and work enthusiasm. In order to reform the employment system and the distribution system, the higher vocational colleges should reach the goal of establishing a fair competitive incentive mechanism for personnel to enter and leave the country, allowing them to adjust their functions and positions, and also have to pay attention to the appointment and remuneration system.

Optimize the Configuration and Realize the Effective Integration of Human Resources. Integrate Internal Human Resources. In order to find and make use of the human resources around them, the leadership of higher vocational colleges should exercise their ability of discerning talents, so as to be able to do well. Because of higher vocational colleges generally lack of an effective talents stimulating mechanism, and the leadership potential of faculty, staff and the ability of future value estimate shortage, lead to many schools appeared a mistake "mediocrity" as "talent" is to blame. Therefore, if vocational colleges want to integrate the existing human resources reasonably and make the staff and workers have a full sense of belonging, sense of accomplishment and sense of participation, and be able to see promising future developments, it is necessary to establish a set of relative perfect human resources integration system and value chain as soon as possible. Only in this way can higher vocational colleges retain the talents that truly meet the needs of the college.

Integrate Social Human Resources. First, In order to enrich the teaching staff of "double-qualification" type and integrate with society, we should make effective use of teachers resources in society, employ some part-time teachers with rich practical experience and reasonably improve the structure of teachers in the college. Second, improve the efficiency of teachers' use, so that the stock of teachers can flow and encourage teachers to go to school. Third, solve the problem of teachers' treatment, take effective measures to improve the wages and salaries of faculty and staff and solve the problems of working and living of external teachers so as to relieve worries and worries. The economic basis determines the superstructure. Only when the economy is stable can we have more energy To work hard, enhance the ability to absorb, stabilize and unite talents, and truly build a contingent of teachers with both ability and political integrity.

Realize Human Resource Sharing. Higher vocational colleges do not have the superior external environment to attract outstanding talents. Therefore, higher vocational colleges should learn to "borrow chicken and lay eggs", try their best to shift from the original human resources to the human resources sharing type, go to ordinary colleges and universities to employ basic disciplines and similar professions and excellent teachers to teach in our hospital. It is necessary to abandon the school-based self-help, in order to effectively achieve the sharing of human resources, but also reduce the operating costs of human capital in higher vocational colleges.

\section{Conclusions}

At present, in order to gain a foothold in the fierce competition in the social market, higher vocational colleges need to use proper and effective incentive measures in human resources management to attract more domestic and overseas talents to serve higher vocational colleges. This promotes school reform and development. Based on human resource management theory and motivation theory, this paper expounds the role of motivation mechanism in human resource management in higher vocational colleges and analyzes the problems existing in incentive mechanism of human resource management in higher vocational colleges. Based on the analysis of 
motivation factors of higher vocational colleges, this paper puts forward the development strategy of human resource management incentive mechanism, which provides theoretical guidance for the improvement of human resource management in higher vocational colleges.

\section{References}

[1] Puentes L M R, Hernández M C, Ramírez E R, et al. Research on construction of the incentive mechanism in the process of higher vocational education implementation of production-learning-research[J]. Journal of Nanchang College of Education, 2013, 14(2):34-40.

[2] Yang Man, Wang Yang. The thinking of the incentive mechanism in human resources management of the vocational colleges[J]. Journal of Wuhan Institute of Shipbuilding Technology, 2009, 8(3): 61-63.

[3] Tian L Y. A Look at the Incentive on Human Resources Management in High Vocational Colleges[J]. Journal of Qingdao Technical College, 2008.

[4] You C J, Hong X P. Application of incentive mechanism in personnel management of higher vocational colleges[J]. Journal of Minxi Vocational \& Technical College, 2017.

[5] Zheng Z, Zhou Q, Polytechnic G I. Research on Incentive Mechanism of Different Shared Subjects in Training Room of Higher Vocational Colleges under Game Theory[J]. Journal of Guangdong Industry Polytechnic, 2017. 